シンポジウム $\mathrm{II}-7$

\title{
LAK 細胞の養子免疫療法と効果の解析
}

\author{
高 後裕・坂牧 純夫
}

Jpn. J. Clin. Immun., 11(5):546 549, 1988.

\section{I.はじめに}

Interleukin 2 (IL-2) により誘導される lymphokine activated killer (LAK) 細胞は, 自己腫瘍細胞に高い障 害性を示すことから，羡子免疫療法 (adoptive immunotherapy）に最適なエフェクター細胞と考えられてい $\Xi^{1,2)}$.

ここでは，現在までに米国および我が国で行われてき た IL-2 による癌治療法の効果を解析するとともに，そ れに付随して生じた問題点とその解決法について触れる こととしたい.

\section{IL-2/LAK 併用療法の現状}

IL-2, LAK 細胞を用いた全身投与による養子免疫療法 は, Rosenberg らにより開始され，1987 年に報告された 結果では, その奏効率 (PR+CR) は, IL-2 単独療法群 で $13 \%$, IL-2+LAK 併用療法群で $22 \%$ であった わち，IL-2 に LAK 細胞移入を併用することによって，治 療成績が向上することが示された. 一方, 我が国でも，2 種の recombinant IL-2 用い, 同様の臨床試験が行わ れた. 我が国での治療成績の特徵は, IL-2 単独投与群 での奏効率は, 約 10\% 前後であり, Rosenberg らのそれ とほぼ同程度であるのに対し，IL-2+LAK 併用投与群で は, IL-2 単独投与群のそれに比べ優位な奏効率を得るに 至らなかったことである. 米国と我が国とで,とくに IL2+LAK 併用療法の奏効率で大きく差の出た原因として は, 投与 IL-2, LAK 細胞移入の頻度, 細胞数ともに我が国 ではより少量で行われたことが主因と考えられている.

一方, 局所に IL-2 単独または IL-2+LAK 併用療法 を施行した場合には，癌性胸・腹膜炎，癌性心葆炎など の体腔内人の癌細胞の貯留例や, 頭頸部癌 - 胃癌, 肝癌

札幌医科大学 第 4 内科
および脳腫場などで有效例が報告されている4,5). 局所投 与による IL-2+LAK 併用療法は従来の抗癌剤または BRM の局所療法に勝るとも劣らない方法であることは， 諸家の一致した認識であり，その理由としては，限局さ れた部分への IL-2 や LAK 細胞の集積が, in vitro で期 待される抗腫瘍効果を生む環境と類似した場面を与える ことによると考えられる．換言すれば，全身投与による 臨床成績の不良は, LAK 細胞が腫煌局所人効率良く集積 し難く，かつ必要 IL-2 濃度の持続が十分でないことを 裏付けている.

\section{IL-2/LAK 併用療法の解析}

この間に得られた経験をもとに, IL-2+LAK 併用療法 に関する現況と問題点からその解決方法について考えて みると、 3 段階に分けて提えることができる.すなわち， (1)癌患者からの大量のリンパ球の採取, (2) in vitro での 大量培養による LAK 細胞の生成，および (3) LAK 細胞 の患者への移入である.第 1 段階であるリンパ球採取は， 自動血球分雄装置を用い， 1 回当り $2 \times 10^{9}$ から $1 \times 10^{10}$ の末梢血リンパ球を採取する訳であるが, 患者, 術者相方 の負担は大きく，ことに我が国のように担当医師が直接 採血に携わる必要がある時のそれは予想以上であり, 継 続的, 頻回の臨床治験を妨げる大きな要因であった.ま た, 第 2 段階の in vitro での大量培恙については, 従来行 われてきたローラー・ボトルやスピナー・フラスコによ る方法は，設備が大がかりとなり，かつ必要陚薬，メディ ウムともに大量に消費するとともに，担当術者に対する 負担も第 1 段階と同様に大きいものであった. これらの 点は, 自動血球分離装置の改善による attending time の短縮や，従来の培養装置にかえて，air permeable culture bag, ホロー・ファイバー型培養装置，透析培盖装 置の導入などで, 培義細胞密度を高ぬ，装置の小型化をは かるとともに，培養条件を改善するなどの試みが行われ 
表 1 各種培養法の比較

\begin{tabular}{|c|c|c|c|}
\hline & spinner flask & $\begin{array}{l}\text { STERI CELL } \\
\text { large cell culture bag } \\
\text { (P/N NCC } 910, \text { DUPONT) }\end{array}$ & $\begin{array}{l}\text { high density } \\
\text { dialyzing culture } \\
\text { system }\end{array}$ \\
\hline \multicolumn{4}{|l|}{ cell density } \\
\hline $\begin{array}{l}\text { initial } \\
\text { final }\end{array}$ & $\begin{array}{r}1 \times 10^{6} / \mathrm{m} l \\
0.5 \times 10^{6} / \mathrm{m} l\end{array}$ & $\begin{array}{r}2 \times 10^{6} / \mathrm{m} l \\
1.4 \times 10^{6} / \mathrm{m} l\end{array}$ & $\begin{array}{l}1 \times 10^{7} / \mathrm{m} l \\
2 \times 10^{7} / \mathrm{m} l\end{array}$ \\
\hline culture volume & $1,000 \mathrm{ml}$ & $2,000 \mathrm{ml}$ & $200 \mathrm{ml}$ \\
\hline culture period & 4 days & 4 days & 30 days \\
\hline \multicolumn{4}{|l|}{ LAK activity } \\
\hline $\begin{array}{l}\text { Daudi } \\
\text { K } 562\end{array}$ & $\begin{array}{l}58.8 \text { L.U. } \\
76.9 \text { L.U. }\end{array}$ & $\begin{array}{l}\text { 316. } 4 \text { L.U. } \\
\text { 438.9 L.U. }\end{array}$ & $\begin{array}{r}806.5 \text { L.U. } \\
1,600.0 \text { L.U. }\end{array}$ \\
\hline required serum & $100 \mathrm{~m} l$ & $200 \mathrm{ml}$ & $20 \mathrm{~m} l$ \\
\hline $\begin{array}{c}\text { required rIL-2 } \\
\text { (per } 1 \times 10^{9} \text { LAK cells) }\end{array}$ & $5.7 \times 10^{3}$ units & $5.7 \times 10^{3}$ units & $2.0 \times 10^{3}$ units \\
\hline cell viability & $50 \sim 60 \%$ & $60 \sim 80 \%$ & $90 \%<$ \\
\hline
\end{tabular}

つつある6゙. 表 1 には，我々が従来行ってきたスピナー・ フラスコによる培養法と，現在使用中の air permeable bag による培養括よび開発中の透析培養装置を用いた際 の培義細胞密度，使用メディウム量, IL-2 量, 誘導キラ 一活性を比較して示した。後 2 者は, 従来法に比べ術者 の負担，試薬，メディウムなどの消費，使用スペースな どの面の利点があるばかりでなく、より高いキラー活性 の LAK 細胞が得られることが特徴である7). 最後の段 階である LAK 細胞の癌患者への移入方法については， 既に述べたように，局所投与が有効なことは論を待たな いが，実際に臨床的に新しい治療法として認知されるた めには，全身投与による抗腫愓効果が明らかにされる必 要がある. 現状の項で触れたように, Rosenberg らが行 っている方法に基づいて IL-2 量, LAK 細胞投与量を上 げることは，出現する副作用，最大に上敒らる有效率な どを考え合わせると，必ずしも得策とは言えないむむし ろ，より細胞障害活性の高い LAK 細胞を誘導，それを 投与するか，他の BRM ないし抗癌剤を併用して臨床効 果を高める試みが必要とされている.

\section{IL-2/LAK 併用療法の効果增強}

現在までに, IL-2 または IL-2+LAK 細胞と併用して 増强効果が報告された抗腫揚剂は, mitomycin, cyclophosphamide, adriamycin などの抗癌剂や,インターフ エロン, tumor necrosis factor (TNF), PSK, OK 432, $v$ ンチナンなどの BRM があげられている cyclophosphamide (Cy) $は$, suppressor cell の抑制を 介して CTL と IL-2 の併用療法に著しい延命効果をも たらしたり ${ }^{11)}$ ，IL-2 による vascular leek syndrome な どの副作用を軽減して治療効果増強をはたし ${ }^{12)}$ ，また
Cy により LAK の嗹瘍集積性が高まる゙'藏ことなどが報 告されている. ヒトでも，Cy の活性型である 4-hydroperoxy-cyclophosphamide $か^{2}$ in vitro $て ゙ \mathrm{CD} 4^{+}$suppressor/inducer T cell を特異的に障害することや(4)， 実際 IL-2 と Cy との併用により臨床効果が高まること が示され ${ }^{15)}, \mathrm{Cy}$ の併用は LAK 細胞の誘導・移入後の LAK, IL-2 の効果発現に優位に働くもの之期待される. また, Cy は臨床的にも, 白血病, 覀性リンパ腫などで広 く用いられ，かつ投与量に低存した副作用の発現や癌腫 別勃果についても良く知られている抗癌郕であり，IL$2+\mathrm{LAK}$ 併用療法の併用する抗澏剤を選択する際に,

第 1 亿考えるべき薬片と言えよう.

著者らは，表 2 に示すように，活性型 Cy である hydropeoxy-Cy で正常ヒトリンパ球を 120 分間 preincubation した後, 洗浄, IL-2 添加, 4 日後の LAK 活性 をみたところ, Cy 無添加時に比へ， $2.0 \mu \mathrm{g} / \mathrm{m} l$ では増强， $5.0 \mu \mathrm{g} / \mathrm{m} l$ では対照と有意差なく, $10.0 \mu \mathrm{g} / \mathrm{ml}$ では抑制 との結果が得られた。 そこで，患者末梢血中の活性 型 Cy 䟴度を $2.0 \sim 5.0 \mu \mathrm{g} / \mathrm{m} l$ の浱度にまで上㫒させるた めの投与量を考えた場合，既報の薬剤浱度の消失曲線の 検討から $500 \sim 600 \mathrm{mg} / \mathrm{m}^{2}$ の Cy の静注が適当であると 思われた. 実際, 2 例の患者に $600 \mathrm{mg} / \mathrm{m}^{2}$ で Cy 静注後, 肝で代謝，転換された活性型 $\mathrm{Cy}$ 濃度を测定してみる と, 最大值は $3.2 \mu \mathrm{g} / \mathrm{m} l, 24$ 時間後には $0.6 \sim 1.6 \mu \mathrm{g} / \mathrm{m} l$ であり, 免疫ネットワークの modulation, 直接抗腫瘍効 果, 腫瑝組織への集積性の増加などを考えた 場 合, 600 $\mathrm{mg} / \mathrm{m}^{2}$ の $\mathrm{Cy}$ 投与はこれらの因子を満足する量と推定 された.

本年 2 月より，Cy 併用による IL-2+LAK 併用㙩法 の pilot study を開始したが，既に大腸癌肝転移症例 
表 2 活性型 cyclophosphamide (Cy) の LAK 誘導に及ぼす影䅸

\begin{tabular}{|c|c|c|c|c|c|c|}
\hline \multirow{2}{*}{$\begin{array}{l}\text { concentration of } \\
\text { 4-hydroperoxy } \\
\text { cyclophosphamide }\end{array}$} & \multirow{2}{*}{ target } & \multicolumn{4}{|c|}{ specific cytotoxicity } & \multirow{2}{*}{ Lytic Units $/ 10^{7}$} \\
\hline & & $\mathrm{E} / \mathrm{T}$ & 20 & 10 & 5 & \\
\hline $0.0 \mu \mathrm{g} / \mathrm{m} l$ & $\begin{array}{l}\text { Daudi } \\
\text { K } 562\end{array}$ & & $\begin{array}{l}61.1 \\
59.0\end{array}$ & $\begin{array}{l}43.5 \\
38.8\end{array}$ & $\begin{array}{l}27.4 \\
24.5\end{array}$ & $\begin{array}{l}357.1 \\
294.1\end{array}$ \\
\hline $2.0 \mu \mathrm{g} / \mathrm{m} l$ & $\begin{array}{l}\text { Daudi } \\
\text { K } 562\end{array}$ & & $\begin{array}{l}75.8 \\
65.5\end{array}$ & $\begin{array}{l}59.9 \\
58.3\end{array}$ & $\begin{array}{l}39.3 \\
33.2\end{array}$ & $\begin{array}{l}555.6 \\
500.0\end{array}$ \\
\hline $5.0 \mu \mathrm{g} / \mathrm{m} l$ & $\begin{array}{l}\text { Daudi } \\
\text { K } 562\end{array}$ & & $\begin{array}{l}53.3 \\
53.0\end{array}$ & $\begin{array}{l}34.1 \\
38.6\end{array}$ & $\begin{array}{l}20.9 \\
21.2\end{array}$ & $\begin{array}{l}274.0 \\
277.8\end{array}$ \\
\hline $10.0 \mu \mathrm{g} / \mathrm{m} l$ & $\begin{array}{l}\text { Daudi } \\
\text { K } 562\end{array}$ & & $\begin{array}{l}0.3 \\
0.6\end{array}$ & $\begin{array}{l}1.5 \\
1.3\end{array}$ & $\begin{array}{l}0.5 \\
0.7\end{array}$ & $\begin{array}{l}0.3 \\
0.5\end{array}$ \\
\hline
\end{tabular}

IL-2

IL-2 + LAK

$\mathrm{IL}-2+\mathrm{Cy}$

$\mathrm{IL}-2+\mathrm{Cy}+\mathrm{LAK}$
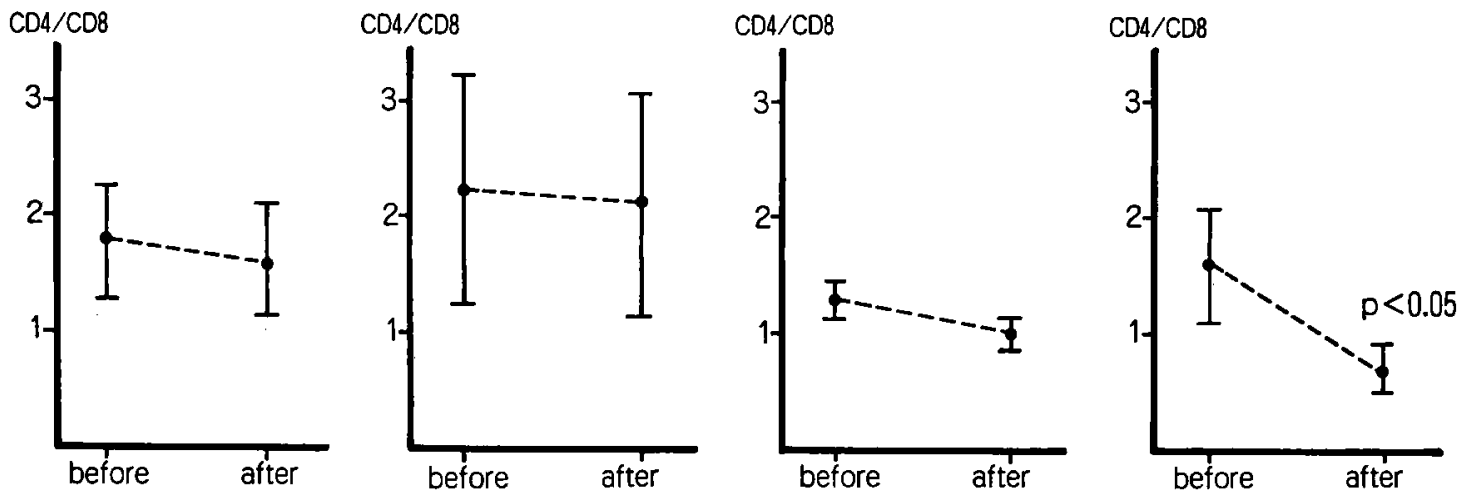

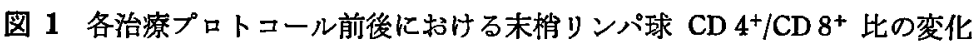

を含め，現在までに 4 例中 2 例の PR 例を認めている. 注目されることは，図１に示すように，併用療法継続中 に明らかな末梢リンパ球の CD 4/CD 8 比の低下がみら れ, 同時に in vitro での IL-2 刺激なしに, NK 活性ばか りでなくLAK 活性が認められるようになったことであ る. 本法の治験は開始したばかりであるので今後の進展 をみたい。

\section{V.おわりに}

LAK 細胞による養子免疫療法の蹦床勃果について，
我が国および米国での成績を比較検討するとともに，著 者らの施設で行っている LAK 療法の問題点扔よびその 解決方法について触れた.

稿を終えるにあたり，共同研究者の蟹沢祐司，野尻秀 一, 上野芳経，伊藤克礼，高橋稔，䈎川祐先生，御校閲 を睗った新津洋司郎教授に深謝いたします。
1) Mazumder, A. et al. : Successful immunotherapy of natural killer-resistant established pulmonary melanoma metastasis by the intravenous adoptive transfer of syngeneic lymphocytes activated in vitro by interleukin-2. J.
Exp. Med., 159 : 495, 1984.

2) Rosenberg, S.A. et al. : Observation of the systemic administration of autologous lymphokine. activated killer cells and recombinant inter. leukin-2 to patients with metastatic cancer. 
N. Engl. J. Med., 313 : 1485, 1985.

3) Rosenberg, S.A. et al. : A progress report on the treatment of 157 patients with advanced cancer using lymphokine-activated killer cells and interleukin-2 or high-dose interleukin-2 alone. N. Engl. J. Med., 316 : 889, 1987.

4）上野芳経・他：癌性心のう炎に IL-2 activated killer cell の局所移入を施行し著効を示した一症 例. 癌と化学療法, $14: 2579,1987$.

5）清水恵司・他：グリオーマ患者における LAK 細 胞の誘導能とその抗腫瘍効果. 脳神経, $38: 265$, 1986.

6) Bach, T. : リンホカイン活性化キラー (LAK) 細 胞の大量生成とがん治療. 発酵と工業, 45 (3) : 231, 1987.

7）高後 裕 ・他：高密度培羕装置を用いた LAK 細 胞の誘導とその効果. Human cell, $1: 54,1988$.

8）西条長宏 - 他：IL-2 の臨床試験. 日本臨床，46: 117, 1988.

9) Owen-Schaub, L.B. et al. : Synergy of tumor necrosis factor and interleukin 2 in the activa. tion of human cytotoxic lymphocytes : Effect of tumor necrosis factor $\alpha$ and interleukin 2 in the generation of human lymphokine-activated killer cell cytotoxicity. Cancer Res., $48: 788$, 1988.
10）沖野 孝・他：乳癌遠隔転移に対する OK-432 併 用 adoptive immunotherapy (AIT) の治療成績. 第 46 回日本癌学会総会記事, 1987.

11) North, R. et al. : Cyclophosphamide-facilitated adoptive immunotherapy of an established $t u$ mor depends on elimination of $t$ umor-induced suppressor T cells. J. Exp. Med., $55: 1063$, 1982.

12) Moshe, Z. et al. : Combined effects of chemotherapy and interleukin 2 in the therapy of mice with advanced pulmonary tumors. Cancer Res., 48 : 122, 1988.

13）森䔖俊彦・他：美子移入 LAK 細胞の腫瘍集積性 のサイクロフォスファマイドによる増強. 第 46 回日本癌学会総会記事, 1987.

14) Ozer, H., Cowens, J.W., Colvin, N. : In vitro effects of 4-hydroperoxy cyclophosphamide on human immunoregulatory $\mathbf{T}$ subset function. I. Selective effects on Iymphocyte function in T, B cell collaboration. J. Exp. Med., 155 : $276,1982$.

15) Kolitz, J.E. et al. : A phase 1 trial of recombinant interleukin 2 and cyclophosphamide in advanced malignancy. Proceeding of A.S.C.O., $5: 235,1986$. 